University of Michigan Law School

University of Michigan Law School Scholarship Repository

\title{
Effect of Covenants in Leases upon Tenant's Right to Remove Trade Fixtures
}

\author{
Ralph W. Aigler \\ University of Michigan Law School
}

Available at: https://repository.law.umich.edu/articles/1091

Follow this and additional works at: https://repository.law.umich.edu/articles

Part of the Property Law and Real Estate Commons, and the State and Local Government Law Commons

\section{Recommended Citation}

Aigler, Ralph W. "Effect of Covenants in Leases upon Tenant's Right to Remove Trade Fixtures." Mich. L. Rev. 11 (1913): 592-3.

This Response or Comment is brought to you for free and open access by the Faculty Scholarship at University of Michigan Law School Scholarship Repository. It has been accepted for inclusion in Articles by an authorized administrator of University of Michigan Law School Scholarship Repository. For more information, please contact mlaw.repository@umich.edu. 
EFfict of Covenants in Leases Upon Tenant's Right to Remove Trade FixTures.-At least since the decision in Poole's Case, I Salk, 368 (I703), it has been considered as settled that a tenant has the right to remove trade fixtures placed upon the demised premises for the purpose of furthering his trade. There is a well-marked tendency in some jurisdictions to greatly extend this right of removal so as to include anything added by the tenant to the leased property "in furtherance of the purpose for which the premises were leased." Hayward v. School District, I39 Mich. 54I, 102 N. W. 999; Bircher v. Parker, 40 Mo. II8; Heddrick v. Smith, I03 Ind. 203; Wittenmeyer v. Board of Education, io O. C. C. IIg. The right of removal, in the cases where it exists, must of course be exercised within the time settled by the law of the jurisdiotion, and the rules in the various states are not entirely harmonious in that regard. For example compare Kerr v. Kingsbury, 39 Mich. 150, with Loughrain v. Ross, 45 N. Y. 792.

This right of removal may be lost not only by failure to remove within the proper time, but also by the terms of the lease. Leases not infrequently contain provisions that the premises shall be delivered up at the end of the term in good order together with "all future erections and additions," of words to similar effect. In a number of cases such general provisions have been before the courts for consideration, the question usually being whether they covered trade fixtures and other fixtures in their nature generally considered as removable. "In Naylor v. Collinge, I Taunt. I9, the things removed were buildings coming within the very words of the covenant; and yet such of them only as were affixed to the freehold, and not such as rested upon blocks were held to be included." Holbrook v. Chamberlin, II6 Mass. 155, I62, In the last cited case the lease contained a covenant to deliver up in good order "all future erections and additions" to or upon the premises. The court held trade fixtures not included. So also in Liebe v. Nicolai, 30 Ore. 364, 48 Pac. I72.

In the late case of Lindsay Bros. v. Curtis Pub. Co., $236 \mathrm{~Pa}$. St. 229, 84 Atl. 783 , the court held that a covenant in a lease that "alterations, improvements and additions" made by the lessee at his own expense on the premises shall at the option of the lessor, remain on the premises and become the property of the lessor, did not cover electric power and lighting appliances installed by the tenant for the more convenient prosecution of its printing business. The court said that "The same sound policy of the law which favors a tenant in the matter of the removal of trade fixtures requires that in the construction of an agreement containing words whose meaning is doubtful the construction of the words most favorable to the tenant shall prevail. Nothing short of the clearest expression of an agreement by the parties to that effect can justify the extension of the grasp of the landlord so as to cover chattels, or personal property, brought upon the premises by the tenant, in pursuance of the business for which the premises were leased." Ten months later the Circuit Court of Appeals for the Third Circuit, in a Pennsylvania case, held in Reber v. Conway, 203 Fed. 12, that a covenant in a lease that "all improvements or additions made by the lessee shall not be detached from the property, but shall remain for the benefit of the lessor" prevented a lessee 
from removing certain machines conceded by the court otherwise to be removable trade fixtures. The ground of the decision seems to be the meaning of the word "detached" considered in view of the fact that the lessee had rented a building arranged for a stable for the purpose of running an ice cream manufactory and had altered the building to make it available for that purpose.

In Re Hozeard Lanndry Co., 203 Fed. 445, the Circuit Court of Appeals for the Second 'Circuit held that a clause in a lease providing that "all additions and improvements which may be made by either party to or upon said premises shall be the property of the landlord" did not cover trade fixtures in the form of machinery otherwise of a removable character. The court said: "The presumption is that trade fixtures belong to the tenant and if it be the intention of the parties that they shall become the property of the landlord at the expiration of the lease, that purpose should be stated in language so clear and explicit that there can be no doubt as to its meaning." Surely the language of the lease in Reber v. Conway, supra, was not of that clear and explicit character. It is believed that the court in the last mentioned case placed a construction upon the word "detached" and the language of the covenant not warranted by the generally considered prevailing doctrine.

R. W. A. 